\title{
Changes in the phytoplankton diversity of two oxbow lakes in a big city: a case study of Wrocław (Poland)
}

\section{Dorota Richter* \& Paulina Bączek}

Wrocław University of Environmental and Life Sciences, Department of Botany and Plant Ecology, pl. Grunwaldzki 24a, 50-363 Wrocław, Poland

* corresponding author (e-mail: dorota.richter@up.wroc.pl)

\begin{abstract}
The subject of this study is to analyse changes in the taxonomic structure and development intensity of phytoplankton and, thus, to determine the diversity of cyanobacteria and algae along with the trophy state of two oxbow lakes in the Wrocław area (south-western Poland). The analysis of samples and data from previous years showed a total of 244 cyanobacteria and algae species within these two lakes. The species composition changed significantly in both of them - there were found 90 species new to the studied flora (37\% of current flora) and 74 species which were previously recorded. The diversity of cyanobacteria and algae reflects the conditions in these water bodies and each change in ecological conditions (e.g., anthropological dangers) is reflected by a change in the phytoplankton assemblage structure. Consequently, knowledge of taxonomic diversity is useful in monitoring water bodies to preserve them in good conditions. Both studied oxbow lakes belong to eutrophic ecosystems as evidenced by their phycoflora, which is rich in species characteristic of high-trophy water, and recorded water blooms. The analysis of changes in cyanobacterial and algal assemblages in these lakes was also a basis for determining their trophy and finding it to be progressively eutrophic. Regular phycological studies of Wrocław numerous water bodies are essential and, in the future, will allow us to protect them and to react quickly in case of danger to these ecosystems. It will also allow us to study eutrophication processes in the water bodies that are crucial to the city.
\end{abstract}

Key words: phytoplankton composition, trophic status, environmental monitoring, oxbow lakes

\section{Introduction}

In cities located on big rivers, a vast network of surface water gives them a unique character. They have numerous water bodies left behind in the old river channels of regulated rivers. Wrocław is located within the hydrographic hub of the Odra and some of its tributaries and provide, therefore, a good location for phycological studies. The Odra branches out into several canals and river-arms which make the hydrographic network diverse. The regulation of the Odra river-bed, for shipping purposes and for flood protection, contributed to the formation of many oxbow lakes in the city area (Bieroński \& Tarka 2010) and, consequently, different water bodies in Wrocław were subjects of many phycological studies (Hilse 1865, 1866; Kirchner 1878; Cohn 1884; Schröder 1897, 1899; Gołowin 1957; Panek 1976; Panek \& Burzyński 1985; Panek et al. 1990, 1991; Dudek-Łacek 2007; Richter \& Matuła
2003, 2004, 2012; Richter 2006, 2013; Bączek 2013). Knowledge about water ecosystems in this area, their biological diversity, functioning and the connection with the landscape is still insufficient. Such studies are crucial because there could be not only rare species to be discovered but also interesting biocoenotic structures. Therefore, the main goal of this study was to determine, both qualitatively and quantitatively, the current cyanobacteria and algae composition of the flora in two oxbow lakes in Szczytnicki Park in Wrocław. The additional data about phytoplankton were used to determine the ecological status of these water bodies as required by the Water Framework Directive (Lyche-Solheim et al. 2013; Napiórkowska-Krzebietke \& Hutorowicz 2014), which allowed us to ascertain the trophy level in the studied lakes.

Water ecosystems in urban areas are susceptible to the city dynamics, which is reflected in the rate and intensity of anthropogenic factors. The development of 


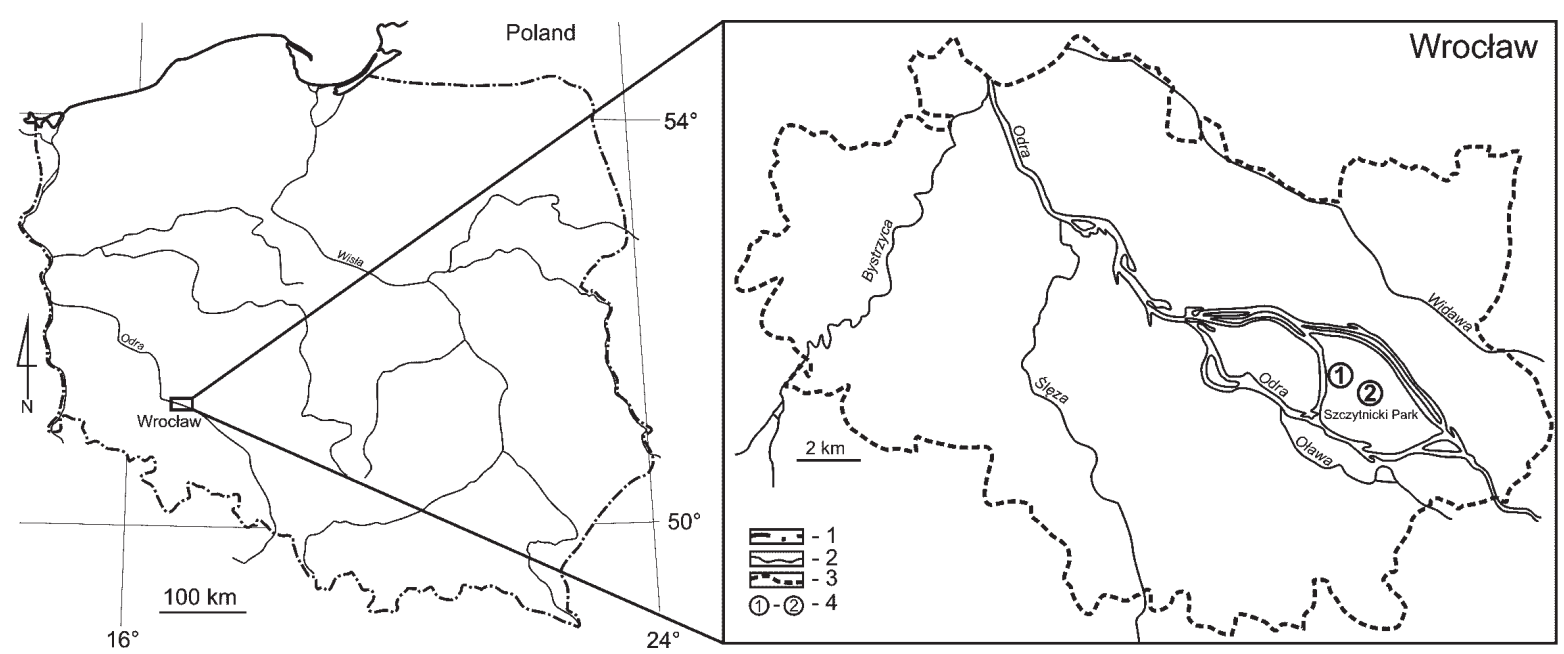

Fig. 1. Location of the studied oxbow lakes in the Wrocław area

Explanations: 1 - state border, 2 - rivers, 3 - city border, 4 - studied oxbow lakes (see Table 1)

urban infrastructure, housing and industrial facilities, negatively influence the characteristics of water habitats. Qualitative changes are, however, directly influenced by eutrophication of water bodies, increases in fertility, air pollution, and climate warming. All these factors cause differences in the species diversity of cyanobacteria and algae (Messyasz \& Jurgońska 2003; Wołowski 2003). By analyzing the species composition and quantitativeness of phytoplankton in a proper time-frame, we obtain information about water ecosystems and, in particular, about the changes in these water bodies (Burchardt 1994; Reynolds 1997; Carvalho et al. 2012). As data on cyanobacteria and algal flora of the studied oxbow lakes were available from previous investigations (Richter 2006; Dudek-Łacek 2007), the newer study provided valuable comparative material allowing us to determine changes in phycoflora over several years. Systematic biological studies provide quality control for these water bodies and allow us to conduct monitoring research aimed at maintaining their good condition. The moni-

Table 1. Study area - the characteristics of examined oxbow lakes

\begin{tabular}{|c|c|c|}
\hline \multirow[t]{2}{*}{ Morphometric features } & \multicolumn{2}{|c|}{ Oxbow lake } \\
\hline & No. 1 & No. 2 \\
\hline Situated in Wrocław & $\begin{array}{l}\text { Szczytnicki Park, in the Centennial } \\
\text { Hall area, near Mickiewicz street }\end{array}$ & Szczytnicki Park, near Heweliusz street \\
\hline Latitude-Longitude & $\begin{array}{l}51^{\circ} 0631.1^{\prime} \mathrm{N}, \\
\text { ADPOLBE-49 }\end{array}$ & $\begin{array}{l}51^{\circ} 066^{\prime} 29.63^{\prime \prime} \mathrm{N}, \\
\text { ADPOLBE-49 }\end{array}$ \\
\hline Total surface area & $6927 \mathrm{~m}^{2}$ & $1200 \mathrm{~m}^{2}$ \\
\hline Depth & $70-100 \mathrm{~cm}(\max .150 \mathrm{~cm})$ & $50-60 \mathrm{~cm}(\max .100 \mathrm{~cm})$ \\
\hline Shape & $\begin{array}{l}\text { elongated, tape-like, extended at one } \\
\text { end }\end{array}$ & kidney shaped \\
\hline Shores & irregular, encased with stones & encased with stones \\
\hline Parts of the water reservoirs & Veg & tations \\
\hline Shore area & $\begin{array}{l}\text { Typha latifolia L., Schoenoplectus } \\
\text { lacustris (L.) Palla, the part in the } \\
\text { Japanese Garden planned artificially } \\
\text { (collections of exotic plants) }\end{array}$ & $\begin{array}{l}\text { Juncus articulatus L. em. K. Richt., } \\
\text { Carex acuta L. and single clumps of } \\
\text { Glyceria maxima (Hartm.) Holmb. }\end{array}$ \\
\hline Middle part & - & $\begin{array}{l}\text { clumps of Phragmites australis (Cav.) } \\
\text { Trin ex Stued. and Schoenoplectus } \\
\text { lacustris (L.) Palla }\end{array}$ \\
\hline Water surface & $\begin{array}{l}\text { Nuphar luteum (L.) Smith, Nymphaea } \\
\text { alba } \mathrm{L} \text {. }\end{array}$ & $\begin{array}{l}\text { Nymphaea alba L., Nuphar luteum (L.) } \\
\text { Smith, Lemna minor L., Potamogeton } \\
\text { sp. }\end{array}$ \\
\hline Bottom & - & Ceratophyllum demersum L. \\
\hline
\end{tabular}



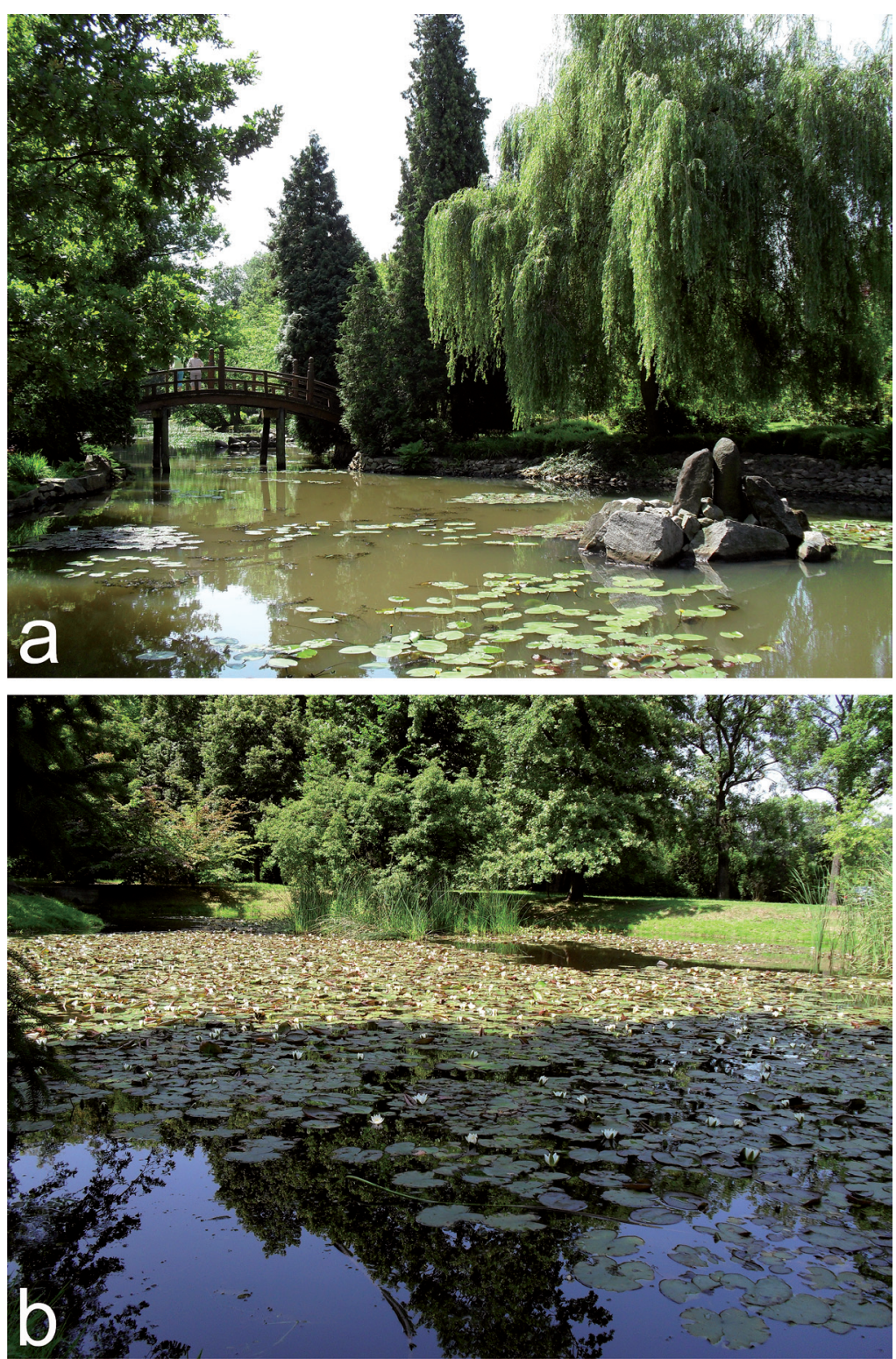

Fig. 2. Study area - the view of studied oxbow lakes: a - near Mickiewicz street (No. 1), b - near Heweliusz street (No. 2)

toring of urban water bodies is always crucial because their attractiveness gives them aesthetic and touristic value. Their recreational values make it essential to keep them clean. Proper characteristics of phycoflora of water bodies that are representative for Wrocław will allow the constant monitoring of water environment in the city. Additionally, it will make possible to establish proper protection of numerous water bodies, canals and branches of the Odra river and a swift reaction in case of danger to these ecosystems.

\section{Material and methods}

\subsection{Study sites and sampling}

The phycological research was conducted between June and September 2013. The samples of cyano- bacteria and algae were taken twice a month. Plankton net with $25 \mu \mathrm{m}$ mesh diameter was used to collect the study material. The concentrated material was gathered into $200 \mathrm{ml}$ plastic containers. The identification was performed live (fresh samples). Species observation was conducted with a Nikon Eclipse TE2000-S digital microscope equipped with a Nikon DS-Fil camera. Quantitative analyses were conducted following the Utermöhl method (Utermöhl 1958). In order to prepare the samples for quantitative analyses, 51 of water were poured through the net and, then, concentrated to $200 \mathrm{ml}$. Such material was observed using a chamber (HYDRO-BIOS no. 435016). The quantitativeness of particular taxa was determined under the microscope using modified Starmach's 6-grade scale (1955), where 1 means the individual occurrence of a given species; 
Table 2. Physical and chemical parameters of water from the examined oxbow lakes

\begin{tabular}{llccc}
\hline \multirow{2}{*}{ Parameter } & \multirow{2}{*}{ Unit } & \multicolumn{3}{c}{ Oxbow lake } \\
\cline { 3 - 5 } & & No. 1 & \multicolumn{2}{c}{ No. 2 } \\
\cline { 3 - 5 } & & 2013 & $2006-2008^{* *}$ & 2013 \\
\hline reaction & $\mathrm{pH}$ & 7.11 & $7.6^{*}$ & 7.10 \\
conductivity & $\mu \mathrm{S} / \mathrm{cm}^{3}$ & 2012 & $1180^{*}$ & 762.3 \\
oxidation $\left(\mathrm{COD}_{\mathrm{Mn}}\right)$ & $\mathrm{mgO}_{2}{ }^{-1}$ & 5.20 & $5.09^{*}$ & 4.80 \\
\hline
\end{tabular}

Explanations: * - mean values of four replicates, ${ }^{*} *$ - from Richter 2012

2 - from 1 to 6 units on standard viewing surface; 3 from 7 to 20 units on standard surface; 4 - from 1 to 10 visible units; 5 - from 11 to 30 visible units; 6 - water blooms (over 30 units in every field).

The taxonomic classification was conducted in accordance with Hoek et al. (1995). Species names were updated according to the detailed literature on the species (Wacklin et al. 2009; Komárek 2016).

Two natural water bodies located within the city of Wrocław (south-western Poland) were chosen for the study (Figs. 1-2, Table 1).

\subsection{Physical, chemical and statistical analyses}

Physicochemical property analyses of the studied oxbow lakes were also conducted (Table 2). The samples for physicochemical analyses in 2013 were collected at about 12.00 , individually in case of both oxbow lakes, on 15.04.2013. In 2006-2008, the samples were collected four times, in the afternoon, on 5.04.2006, 10.04.2006, 10.10.2008 and 15.10.2008. In the studied lakes, the samples were collected $1 \mathrm{~m}$ from the bank, at the depth of $20-30 \mathrm{~cm}$, in water free from aquatic plants. $\mathrm{pH}$ and conductivity were measured using PN90/C-0440.01 and oxygen concentration with PN-ESISO 8467.

Statistical analyses were performed using STATISTICA v. 12 packages (StatSoft Inc., 2014). Shannon's diversity index (Shannon \& Weaver 1949) was used to describe species diversity and evenness.

\section{Results}

\subsection{Phytoplankton composition of the studied oxbow lakes}

The studied ecosystems are characterized by qualitatively rich phytoplankton composition. Particular cyanobacterial and algal assemblages have diverse taxonomic composition. They differ in species number, quantitative arrangement, the share of particular taxonomic groups and taxonomic diversity. The Diversity Index of cyanobacteria and algae in the studied oxbow lakes was high with a slightly higher species diversity in the lake no. 2. Evenness Index in both examined water bodies showed a diverse species share in cyanobacterial and algal assemblages (Table 3). The phycoflora of the studied; lakes showed a clear dominance of Bacillariophyceae (82 taxa, 33\% of all recorded species) and Chlorophyceae (57 taxa, 23\% of all recorded species). Within this group, the highest number of species and species diversity along with species with higher quantitative scale was found to occur, which distinguished the lakes as diatoms-green algae structure (Appendix 1). The shares of these groups differed between both water bodies. In the oxbow lake no. 1, the number of diatoms was twice higher than Chlorophyceae, whereas it was very similar in the oxbow lake no. 2. In the case of other groups, the study revealed 47 taxa of Euglenophyta (19.3\% of all recorded species) and 35 taxa of Cyanophyta (14.4\% of phycoflora). Dinophyta (2 taxa, $0.82 \%$ ) and Cryptophyta ( 1 taxon, $0.4 \%$ ) were the least numerous (Table 3). The studied lakes also had an increased number of Cyanophyceae and Euglenophyceae species and some of these species contributed to water blooms.

\subsection{Changes in time in cyanobacteria and algal flora} of the studied oxbow lakes

Current results, as compared to data from previous years (Richter 2006; Dudek-Łacek 2007), suggest that the total number of cyanobacteria and algae taxa found in the studied oxbow lakes grew insignificantly or remained the same. However, there was a change in species composition. Ninety new species were found to occur in the studied flora and only 74 previously recorded species were confirmed (Table 3 ).

In the oxbow lake no. 1 significant changes occurred in the combination of species of particular types. Many hitherto occurring species disappeared and new species emerged in their place (50 new taxa, over $60 \%$ of current flora). The biggest change was noticed in the emergence of 15 new Euglenophyta class taxa. This is particularly important as species belonging to this class were not recorded earlier in this water body. Both previously and now, within blue-greens, there were blooms of Microcystis aeruginosa. In the group of diatoms, most 
Table 3. The number of species found in the studied oxbow lakes showing temporal changes and the values of biodiversity and evenness indices of phycoflora

\begin{tabular}{|c|c|c|c|c|c|}
\hline \multirow{3}{*}{ Taxonomical groups } & \multicolumn{4}{|c|}{ Oxbow lake } & \multirow{3}{*}{ Sum of all } \\
\hline & \multicolumn{2}{|c|}{ No. 1} & \multicolumn{2}{|c|}{ No. 2} & \\
\hline & $2006-2007^{*}$ & 2013 & $2006-2008 * *$ & 2013 & \\
\hline Phyla Cyanophyta & 9 & 9 & 15 & 15 & 35 \\
\hline Class Cyanophyceae & 9 & 9 & 15 & 15 & 35 \\
\hline number of species not previously reported & & 5 & & 8 & \\
\hline number of species not confirmed & & 5 & & 8 & \\
\hline number of species confirmed & & 4 & & 7 & \\
\hline Phyla Heterokontophyta & 44 & 42 & 35 & 32 & 96 \\
\hline Class Bacillariophyceae & 42 & 39 & 28 & 27 & 82 \\
\hline number of species not previously reported & & 18 & & 9 & \\
\hline number of species not confirmed & & 21 & & 10 & \\
\hline number of species confirmed & & 21 & & 18 & \\
\hline Class Chrysophyceae & 2 & 1 & 0 & 0 & 3 \\
\hline number of species not previously reported & & 1 & & 0 & \\
\hline number of species not confirmed & & 2 & & 0 & \\
\hline number of species confirmed & & 0 & & 0 & \\
\hline Class Xanthophyceae & 0 & 2 & 7 & 5 & 9 \\
\hline number of species not previously reported & & 2 & & 1 & \\
\hline number of species not confirmed & & 0 & & 3 & \\
\hline number of species confirmed & & 0 & & 4 & \\
\hline Phyla Euglenophyta & 0 & 15 & 21 & 26 & 47 \\
\hline Class Euglenophyceae & 0 & 15 & 21 & 26 & 47 \\
\hline number of species not previously reported & & 15 & & 16 & \\
\hline number of species not confirmed & & 0 & & 11 & \\
\hline number of species confirmed & & 0 & & 10 & \\
\hline Phyla Chlorophyta & 21 & 16 & 36 & 31 & 65 \\
\hline $\begin{array}{l}\text { Class Chlorophyceae } \\
\text { number of species not previously reported }\end{array}$ & 18 & $\begin{array}{c}14 \\
6\end{array}$ & 30 & $\begin{array}{l}27 \\
15\end{array}$ & 57 \\
\hline number of species not confirmed & & 10 & & 18 & \\
\hline number of species confirmed & & 8 & & 12 & \\
\hline Class Cladophorophyceae & 0 & 1 & 1 & 1 & 1 \\
\hline number of species not previously reported & & 1 & & 0 & \\
\hline number of species not confirmed & & 0 & & 0 & \\
\hline number of species confirmed & & 0 & & 1 & \\
\hline Class Zygnematophyceae & 3 & 1 & 5 & 3 & 7 \\
\hline number of species not previously reported & & 1 & & 1 & \\
\hline number of species not confirmed & & 3 & & 3 & \\
\hline number of species confirmed & & 0 & & 2 & \\
\hline Phyla Dinophyta & 0 & 1 & 0 & 1 & 2 \\
\hline Class Dinophyceae & 0 & 1 & 0 & 1 & 2 \\
\hline number of species not previously reported & & 1 & & 1 & \\
\hline number of species not confirmed & & 0 & & 0 & \\
\hline number of species confirmed & & 0 & & 0 & \\
\hline Phyla Cryptophyta & 0 & 0 & 0 & 1 & 1 \\
\hline Class Cryptophyceae & 0 & 0 & 0 & 1 & 1 \\
\hline number of species not previously reported & & 0 & & 1 & \\
\hline number of species not confirmed & & 0 & & 0 & \\
\hline number of species confirmed & & 0 & & 0 & \\
\hline Total number of species & 74 & 83 & 107 & 106 & 244 \\
\hline Total number of species previously reported & & 50 & & 52 & 90 \\
\hline Total number of species not confirmed & & 41 & & 53 & 80 \\
\hline Total number of species confirmed & & 33 & & 54 & 74 \\
\hline Diversity index & 4.20 & 4.30 & 4.56 & 4.53 & \\
\hline Evenness & 0.977 & 0.972 & 0.975 & 0.972 & \\
\hline
\end{tabular}


of them occurred in higher quantitativeness and many of them increased their quantitativeness. Current flora, as compared to earlier years, exhibited changes in the dominants within Chlorophyceae. In 2007, Desmodesmus protuberans and Pandorina sp. 2 were dominant, whereas in 2013 - Chloromonas sp. formed water blooms along with numerous accompanying Scenedesmus sp. 3.

In the case of the oxbow lake no. 2, changes were also visible in the species combinations of particular classes and in the quantitativeness. Within Cyanophyceae, there was an increase in the species characteristic of eutrophic species, such as Microcystis aeruginosa, $M$. novacekii, which increased their share in cyanobacteria assemblages. Aphanocapsa incerta was also recorded in a higher quantity. Their increased share, along with new species characteristic of eutrophic water bodies, may suggest increased trophy of this lake. The biggest species similarity between current phycoflora and earlier phycoflora was observed in the diatom assemblage because 18 out of 27 taxa were confirmed, which constitutes almost $70 \%$ of unchanged group composition. The highest number of previously unrecorded species was within Euglenophyceae (16 taxa). Both previously recorded species and new species were recorded in high quantities. In euglenoid assemblages, the study recorded water blooms of Trachelomonas volvocina with numerous accompanying $T$. hispida, Phacus longicauda, P. longicauda var. tortus. Within Chlorophyta, the study recorded 15 previously absent taxa, particularly coccoid green algae. Additionally, the rocks around the lake had well developed Cladophora glomerata periphyton communities.

\section{Discussion}

\subsection{Phytoplankton composition - a response to change in time}

Species richness, changes in the taxonomic composition and structure, the dynamics of phytoplankton development may indicate, along with other ecosystem elements, the direction of trophy changes in water bodies (Burchardt 1993; Burchardt et al. 1994; Burchardt \& Lastowski 1999; Reynolds 2000; Reynolds et al. 2002).

In both studied oxbow lakes, diatoms and green algae were dominant groups in phytoplankton assemblages. The dominance of Bacillariophyceae and Chlorophyta in flora is typical of eutrophic species (Burchardt et al. $2003,2014)$, which allows us to classify these lakes as high-trophy water bodies. Their eutrophic character is also confirmed by the presence of a large number of typically eutrophic species of Coelastrum, Scenedesmus, Oocystis and Pediastrum genera (Berlinger \& Sigee 2010; Jachniak \& Kozak 2011; Jachniak et al. 2015).
Among coccoid green algae found in the lakes, there were numerous representations of taxa characteristic of high trophy waters, such as: Coelastrum microporum, C. pseudomicroporum, Desmodesmus opoliensis, $\mathrm{Pe}$ diastrum duplex, Scenedesmus obliquus var. dimorphus (Comas et al. 2007). The intensive development of coccoid green algae confirms the eutrophic character of the studied oxbow lakes, because, as a function of their rapid response to environmental conditions, they are a good indicator for identifying and typifying limits and directions of environmental changes in aquatic ecosystems (Burchardt et al. 2003; Comas et al. 2007). On stones in the oxbow lake no. 2, numerous species of Cladophora glomerata were also reported, which is characteristic of eutrophic water bodies (Dodds 1991; Rybak et al. 2012).

The high trophy of the studied oxbow lakes was also suggested by higher quantitativeness of species typical of eutrophic water bodies, such as: Microcystis aeruginosa, M. novacekii, and Aphanocapsa incerta (Komárek \& Anagnostidis 1999). High biomass of cyanobacteria is often found in eutrophic water bodies (Grabowska \& Mazur-Marzec 2011; Grabowska 2012). Both, the oxbow lake no. 1 and no. 2 revealed a significant increase of Euglenophyta species. The occurrence of Euglenophyceae means that the studied lakes are polluted because these taxa occur usually in small and polluted water bodies and in sewage, where high nutrient content is favorable for species of this group (Wołowski 1998, 2003). Additionally, some species of this group formed water blooms. These species indicate a higher concentration of organic matter, which may also suggest increased trophy of the studied water body (Matuła 1995; Owsianny \& Gąbka 2004; Bucka \& Wilk-Woźniak 2007).

Diatoms have long been used in various diatom indices to assess water quality throughout Europe (e. g. Kolkwitz \& Marson 1908; Prygiel 2002; Kelly et al. 2008; Szulc \& Szulc 2013), since they are a good indicator of environment properties. In the oxbow lake no. 1, many species emerged within Bacillariophyceae (18 taxa), including species typical of fertile waters, among others Amphora ovalis, Asterionella formosa, Aulocoseira granulata, A. ambigum, Melosira varians, Fragilaria capucina, Rhoicosphenia abbreviata (Rakowska 2001; Bąk et al. 2012). On the other hand, in the oxbow lake no. 2, within this group, earlier and current studies recorded the following species: Cyclotella meneghiniana, Gomphonema parvulum var. parvulum, Nitzschia palea and Ulnaria ulna - which are characteristic of eutrophic waters (Rakowska \& Szczepocka 2011).

In conclusion, the studies suggest that trophy levels of the oxbow lakes changed in a short period of time. They are still eutrophic, but due to numerous water 
blooms, the increase in quantitativeness of particular species may indicate increasing trophy of these waters. Additionally, the emergence of new species and an increased number of Euglenophyta species as well as their higher quantitativeness may suggest that there is more organic matter in the lakes. Consequently, the analysis of changes in cyanobacterial and algal assemblages of the oxbow lakes provided a basis for conclusions about the trophy of these water bodies and its determination as increasingly eutrophic.

To sum up, it needs to be mentioned that in large urban agglomerations, due to failed anthropic activity, water ecosystems show changes in $\mathrm{pH}$, electrolytic conductivity and nutrient availability. These unfavorable processes lead to distortions in water ecosystems, including phycoflora. Cyanobacteria may react to these factors by changing quantity and quantitativeness of species, taxonomic composition and diversity index. Algae and cyanobacteria respond to environment change very quickly and, thus, may be treated as indicative species. This role is clearly understandable as they are a complex group of organisms having many features useful in evaluating environment stability.

They are relatively simply built and, due to their physiological properties, they quickly react to changes in their habitat and, thus, have an advantage over vas- cular plants. Individual taxa may respond differently to the same environmental factors. They may be used to characterize various environments, including still water habitats mentioned in this paper. They may also indicate seasonal changes and water productivity. Cyanobacteria and algae studied together as all groups help in complex environment evaluation. On the other hand, individual species inform us about particular factors disturbing a habitat. Consequently, we may use both individual species and whole cyanobacteria and algae communities as universal bio-indicators in monitoring the environment and determining fertility, contamination and purity.

Carr et al. (2005) showed that the abundance of periphyton depends on nutrient concentration. Additionally, a shift in dominants in cyanobacterial and algal communities shows the contamination of water basins. Peinador (1999) noticed a larger share of Cyanophyta in more contaminated areas. Higher phosphate and nitrate availability favors the development of green algae. In a study by Akpan \& Akpan (1994), phytoplankton was dominated by Chlorophyceae, which showed the biggest species richness, density and diversity. Such phytoplankton state was caused by the eutrophic character of the pond (sewage entered the water reservoir). The above-mentioned remarks confirm the validity of using cyanobacteria and algae in determining the state and stability of ecosystems.

\section{References}

Akpan A. W. \& Akpan B. E. 1994. Spatial and temporal heterogeneity in plankton distribution in a Nigerian tropical freshwater pond (southern Nigeria). Acta Hydrobiol. 36(2): 201-211.

Carr G. M., Chambers P. A. \& Morin A. 2005. Periphyton, water quality, and land use at multiple spatial scales in Alberta rivers. Canadian Jurnal of Fisheries and Aquatic Sciences 62(6): 1309-1319.

BĄCZEK P. 2013. Analiza zmian flory glonów i sinic dwóch zbiorników wodnych z terenu Parku Szczytnickiego we Wrocławiu. Master's Thesis, The Wrocław University of Environmental and Life Sciences, Wrocław.

Bąk M., Witkowski A., Żelazna-Wieczorek J., Wojtal A. Z., Szczepocka E., Szulc K., Szulc B. \& Wojtal A. 2012. Klucz do oznaczania okrzemek w fitobentosie na potrzeby oceny stanu ekologicznego wód powierzchniowych w Polsce. 452 pp. Biblioteka Monitoringu Środowiska. Główny Inspektorat Ochrony Środowiska, Warszawa:

Berlinger E. G. \& Sigee D. C. 2010. Algae as Bioindicators. In: E. G. Bellinger \& D. C. Sigee (eds.). Freshwater Algae: Identification and Use as Bioindicators, pp. 99-136. Copyright John Wiley \& Sons Ltd.

Bieroński J. \& TARKA R. 2010. Zasoby wodne na terenie Wrocławia. In: Z. Lewicki (ed.). Środowisko Wrocławia Informator, pp. 40-110. LEMITOR
Ochrona Środowiska, Oficyna Wydawnicza ATUT, Wrocław.

Bucka H. \& WiLK-WoźNiaK E. 2007. Future in past: a review of phytoplankton studies conducted In southern Poland over the past fifty years. Oceanol Hydrobiol St 36: 67-76.

BurChARDT L. 1993. Bioindication in the assessment of lake ecosystem. In: L. BurchardT (ed.). Theory and practice in ecosystems research. Idee Ekologiczne 3(2): 39-44.

BurchardT L. 1994. Bioindykacja w ocenie ekosystemu jeziornego. In: L. BuRCHARDT (ed.). Teoria i praktyka badań ekologicznych. Idee Ekologiczne 4(3): 71-76.

Burchardt L., Hindák F., Komárek J., Lange-Bertalot H., Messyasz B., Pikosz M., Wejnerowski Ł., Jakubas E., RYBAK \& GĄBKA M. 2014. Spring phytoplankton and periphyton composition: case study from a thermally abnormal alkes in Western Poland. Biodiv. Res. Conserv. 36: 17-24.

Burchardt L. \& Łastowski K. 1999. The problem of using common species in bioindication: Basis term. Acta Hydrobiol. 41(3-4): 231-234.

BurChARDT L., ŁastowsKi K. \& SzMAJdA P. 1994. Różnorodność ekologiczna a bioindykacja. In: L. BuRCHARDT (ed.). Teoria i praktyka badań ekologicznych. Idee Ekologiczne 4(3): 27-43. 
Burchardt L., Messyasz B., Owsianny P. M., Pelechata A. \& Stefaniak K. 2003. Chlorococcalean algae from four lakes in the Slowinski National Park (Northern Poland). Biologia 58(4): 467-474.

Carvalho L., Poikane S. A., Lyche Solheim A., Phillips G., Borics G., Catalan J., De Hoyos C., Drakare S., Dudley B. J., Järvinen M., Laplace-Treyture C., Maileht K., McDonald C., Mischke U., Moe J., Morabito G., Nõges P., Nõges T., Ott I., Pasztaleniec A., SkJelbred B. \& Thackeray S. J. 2012. Strength and uncertainty of phytoplankton metrics for assessing eutrophication impacts in lakes. Hydrobiologia 704(1): 127-140.

CoHN F. 1884. Über ein merkwürdiges Vorkommen von Algen in den Breslauer Waschteichen. Jahresber, Schles. Ges. Vaterl. Cult. 61: 190.

Comas A., Novelo E. \& Tavera R. 2007. Coccal green algae (Chlorophyta) in shallow ponds in Veracruz, México. Algological Studies 124: 29-69.

DodDs W. K. 1991. Factors associated with dominance of the filamentous green alga Cladophora glomerata. Water Research 25(11): 1325-1332.

Dudek-ŁaceK R. 2007. Bioróżnorodność sinic i glonów, a stan środowiska wodnego na przykładzie zbiornika wodnego na terenie Ogrodu Japońskiego (Park Szczytnicki). Master Thesis's, The Wrocław University of Environmental and Life Sciences, Wrocław.

GrabowsKa M. 2012. The role of eutrophic lowland reservoir in shaping the composition of river phytoplankton. Ecohydrology and Hydrobiology 12(3): 231-242.

Grabowska M. \& Mazur-Marzec H. 2011. The effect of cyanobacterial blooms In the Siemianówka Dam Reservoir on the phytoplankton structure in the Narew River. Oceanol Hydrobiol St 40(1): 19-26.

GoŁowIN S. 1957. Glony planktonowe stawku Wrocławskiego Ogrodu Botanicznego. Zeszyty Naukowe Wrocławskiego Ogrodu Botanicznego 2: 73-86.

HiLsE W. 1865. Beiträge zur Algenkunde Schlesiens insbesondere Breslau. Jahres-Ber. Schles. Ges. Vaterl. Cult. 42: 77-100.

Hilse W. 1866. Beiträge Zur Algenkunde Schlesiens, als Fortsetzung der Beiträge im Jahres Bericht für 1864. Jahres-Ber. Schles. Ges. Vaterl. Cult. 43: 109-29.

Hoek C., Mann D. G. \& Johns H. M. 1995. Alga: an introduction to phycology. 623 pp. Printed in Great Britain at University Press, Cambridge.

JACHNIAK E. \& KozAK J. L. 2011. Glony planktonowe-bioindykatory poziomu zeutrofizowania dwóch zbiorników zaporowych: Wapienicy i Kozłowej Góry. Monitoring Środowiska Przyrodniczego 12: 43-50.

JaChniak E., HolubČIK M., Ćmiel M. \& Gazda K. 2015. Ocena stanu troficznego wód zbiornika zaporowego Wapienia. Inżynieria Ekologiczna 41: 181-187.

Kelly M. G., Juggins S., Guthrie R., Prichard S., Jamieson J., Rippey B., Hirst H. \& Yallop M. 2008. Assessment of ecological status in U. K. rivers using diatoms. Freshwater Biology 53: 403-422.

KIRCHNER G. 1878. Kryptogamen-Flora von Schlesien, Algen, Kern's Verlag, Breslau 2(1): 284.

Kolkwitz R. \& Marson M. 1908. Ökologie der tierischen Saprobien, Berichte der Deutschen Botanischen Gesellschaft 26a: 505-519.
KomÁreK J. \& Anagnostidis K. 1999. Cyanoprokaryota; Chroococcales I. In: A. PAscher (ed.). Süßwasserflora von Mitteleuropa, pp. 549. Gustav Fischer Jena Stuttgart Lübeck Ulm.

KoMÁREK J. 2016. Review of the cyanobacterial genera implying planktic species after recent taxonomic revisions accoeding to polyphasic methods: state as of 2014 . Hydrobiologia 764: 259-270.

Lyche-Solheim A., Feld CH. K., Birk S., Phillips G., Carvalho L., Moabito G., Mischke U., Willby N., Søndergaard M., Hellsten S., Kolada A., Muelde M., Khmer J., Miler O., Pusch M. T., Argillier Ch., Jeppesen E., Lauridsen T. L. \& Poikane S. 2013. Ecological status assessment of European lakes: a comparison of metrics for phytoplankton, macrophytes, benthic invertebrates and fish. Hydrobiologia 704: 57-74.

MatuŁA J. 1995. Warunki troficzne glonów torfowiskowych na obszarze Dolnego Śląska. Zesz. Nauk. AR we Wrocławiu 135: 1-132.

McGowan S. Leavitt P. R. Hall R. I., Anderson N. J., JeppeSEN E. \& OdgaArd B. V. 2005. Controls of algal abundance and community composition during ecosystem state change. Ecology 86(8): 2200-2211.

Messyasz B. \& JuRgońsKa M. 2003. Struktura gatunkowa fitoplanktonu w cyklu rocznym w stawach Dużym i Małym (park Sołacki, Poznań). Rocz. AR Pozn. CCCLIV, Bot. 6: 131-145.

Napiórkowska-Krzebietke A. \& Hutorowicz A. 2014. Phytoplankton In an ecological status assessment of the vendace-type Lake Dejguny (northeastern Poland). Arch. Pol. Fish. 22: 39-40.

Owsianny P.M. \& GąBKa M. 2004. Roślinność ekosystemów wodnych Krainy Złotowskiej. In: G. ZıóŁKOwski (ed.). Przyroda Krainy Złotowskiej, pp. 38-50. Wlkp. Stow. Pr. Organ. Ekorozwój, Urbański Wyd. Toruń.

PANeK E. S. 1976. O występowaniu Pithophora oedogonia (Mont.) Wittr. var. polyspora Rendle et West fil. (Cladophoraceae) w stawie wrocławskiego Ogrodu Botanicznego. Fragm. Flor. Geobot. 22(1-2): 255-60.

Panek E. S., Biala K. \& Piecuch K. 1991. Glony zbiorników wodnych Wrocławia. II, Acta Univ. Wratisl., Wrocław. 1225: 89-100.

PANeK E. S. \& BurzyŃSKi M. 1985. The algal flora of artificial reservoir in the Wrocław Botanic Garden. Acta Univ. Wratisl. 787: 71-91.

Panek E. S., Grzegórski R. \& Piecuch K. 1990. Glony zbiorników wodnych Wrocławia. I, Acta Univ. Wratisl., Wrocław. 1156: 257-69.

Peinador M. 1999. Cyanobacteria as bioindicators of organic pollution. Revista De Biologia Tropical 47(3): 381-391.

Prygiel J. 2002. Management of the diatom monitoring network in France. Journal of Applied Phycology 14: 19-26.

Rakowska B. 2001. Studium różnorodności okrzemek ekosystemów wodnych Polski niżowej. Wyd. Uniwersytetu Łódzkiego, Łódź.

RAKowska B. \& SzCZEPocka E. 2011. Demonstration of the Bzura River restoration Rusing diatom indices. Biologia 66(3): 411-417. 
ReYNOLDS C. S. 1997. Vegetation processes in the pelagic: A model for ecosystem theory. $371 \mathrm{pp}$. Ecology Institute, Oldendorf/Luhe.

Reynolds C. S. 2000. Phytoplankton designer-or how to predict compositional responses to trophic-state change. Hydrobiologia 424: 67-77.

Reynolds C. S., Huszar V., Kruk C., Naseli-Flores L. \& Melo S. 2002.Towards a functional classification of the freshwater phytoplankton. J. Plankton Res. 24: 417-428.

Richter D. 2006. Bioróżnorodność sinic i glonów jako wskaźnik poziomu trofii ekosystemów wodnych Wrocławia i okolic. Ph. D. Thesis, the Wrocław University of Environmental and Life Sciences, Wrocław.

Richter D. 2013 Analysis of changes in cyanobacterial and algal flora of selected water reservoirs in Wrocław between 1878 and 2010 (south-west Poland). Oceanol Hydrobiol St 42 (4): 279-397.

Richter D. \& MAtuŁa J. 2003. Wstępna charakterystyka fykoflory wybranych zbiorników wodnych Wrocławia. Cz. I. Annales Silesiae 32: 5-18.

Richter D. \& MAtuŁa J. 2004. Wstępna charakterystyka fykoflory wybranych zbiorników wodnych Wrocławia. Cz. II. Annales Silesiae 33: 15-26.

Richter D. \& MatuŁa J. 2012. Response of cyanobacteria and algae community from small water bodies to physicochemical parameters. Oceanol Hydrobiol St 41(2): 18-28.

Rybak A., Messyasz B., Łęska B., Pikosz M. \& Fabrowska J. 2012. Wydajność asymilacji azotu na przykładzie wybranych gatunków roślin wodnych. In: G. ScHRoEDER \& P. GRzesiak (eds.). Środowisko i Przemysł. Cursiva 3(1): 11-42.
SCHRÖDER B. 1897. Attheya, Rhizosolenia und andere Planktonorganismen im Teiche des Botanischen Gartens zu Breslau. Berichte Deutsch. Bot. Gesell. 15: 367-74.

Schröder B. 1899. Das Plankton des Oderstromes. B. Das pflanzliche Plankton der Oder. Forschungsber, Biol. Stat. Plön 7: 15-24.

Shannon C. E. \& Weaver W. 1949. The mathematical theory of communication. $125 \mathrm{pp}$. University of Illinois Press, Urbana.

Starmach K. 1955. Metody badań planktonu. 133 pp. PWRiL, Warszawa.

StATSOFT 2014. Inc. Statistica [data analysis software system]. Version 12. www.statsoft.com.

UTERMÖHL H. 1958. Zur Vervollkommung der quantitative Phytoplankton-Methodik. Mitt. Internat. Verein. Limnol. 9: 1-38.

Szulc B. \& Szulc K. 2013. The use of the Biological Diatom index (BDI) for the assessment of water quality in the Pilica River, Poland. Oceanol Hydrobiol St 42(2): 188-194.

Wacklin P., Hoffmann L. \& KomÁrek J. 2009. Nomenclatural validation of the genetically revised cyanobacterial genus Dolichospermum (Ralfs ex Bornet et Flahault) comb. nova. Fottea 9(1): 59-64.

WoŁowsKi K. 1998. Taxonomic and environmental studies on Euglenophytes of Kraków-Częstochowa Upland (Southern Poland). Fragm. Flor. Geobot. Suppl. 6: 3-192.

WOŁowsKi K. 2003. Różnorodność gatunkowa - glony. In: R. AndRZEJewski \& A. Weigle (eds.). Różnorodność biologiczna Polski, pp. 37-48. Narodowa Fundacja Ochrony Środowiska, Warszawa. 
Appendix 1. The list of cyanobacteria and algae in two oxbow lakes in the Wrocław area: near Mickiewicz street in 20062007 (A) and 2013 (B), and near Heweliusz street in 2006-2008 (C) and 2013 (D), 1-6 quantitative scale

\begin{tabular}{|c|c|c|c|c|}
\hline & $\mathrm{A}$ & $\mathrm{B}$ & $\mathrm{C}$ & $\mathrm{D}$ \\
\hline \multicolumn{5}{|l|}{ Phyla Cyanophyta (Cyanobacteria) } \\
\hline \multicolumn{5}{|l|}{ Class Cyanophyceae } \\
\hline Anabaena oscillarioides Bory de Saint-Vincent ex Bornet \& Flahault & & & & 2 \\
\hline Anabaena sp. & & 1 & & \\
\hline Aphanocapsa holsatica (Lemmermann) G.Cronberg \& Komáre & 1 & & & 3 \\
\hline Aphanocapsa incetera (Lemmermann) Clonberg et Komárek & & 1 & & 3 \\
\hline Calothrix sp. 1 & & & 2 & \\
\hline Calothrix sp. 2 & 1 & & & \\
\hline Geitlerneima sp. & & 1 & & \\
\hline Geitlerinema splendidum (Greville ex Gomont) Anagnostidis & & & 1 & \\
\hline Jaaginema pseudogeminatum (Schmid) Anagnostidis \& Komárek & & & 1 & 1 \\
\hline Kamptonema formosum (Bory de Saint-Vincent ex Gom.) Strun. Kom. \& Smarda & & & 1 & 2 \\
\hline Leptolyngbya angustissima (West \& West) Anagnostidis \& Komárek & 1 & 1 & & \\
\hline Leptolyngbya sp. 1 & 1 & & & \\
\hline Leptolyngbya sp. 2 & & & & 1 \\
\hline $\begin{array}{l}\text { Limnothrix planctonica (Woloszynska) Meffert } \\
\text { Limnoraphis cryptovaginata (Shkorbatov) Komárek, Zapomelová, Smarda, Kopecky, } \\
\text { Rejmámková, Woodhouse, Neilan \& Komárková }\end{array}$ & & & $\begin{array}{l}1 \\
1\end{array}$ & 1 \\
\hline Lyngbya sp. 1 & & & 1 & \\
\hline Lyngbya sp. 2 & & & & 1 \\
\hline Merismopedia glauca (Ehrenberg) Kützing & & & 3 & 2 \\
\hline Merismopedia punctata Meyen & & & & 1 \\
\hline Microcystis aeruginosa (Kützing) Kützing & 5 & 4 & 2 & 3 \\
\hline Microcystis natans Lemmermann ex Skuja & & & & 2 \\
\hline Microcystis novacekii (Komárek) Compére & & & 1 & 3 \\
\hline Microcystis wesenbergii (Komárek) Komárek ex Komárek & 1 & 1 & & \\
\hline Oscillatoria sp. 1 & & & 1 & \\
\hline Oscillatoria sp. 2 & & 1 & & \\
\hline Oscillatoria subbrevis Schmidle & & & 1 & 1 \\
\hline Planktolyngbya lacustris (Lemmermann) Anagnostidis \& Komárek & & & 1 & \\
\hline Phormidium aerugineocaeruleum (Gomont) Anagnostidis \& Komárek & & & 1 & \\
\hline Phormidium granulatum (Gardner) Anagnostidis & 3 & 1 & & \\
\hline Phormidium irriguum (Kützing ex Gomont) Anagnostidis \& Komárek & 1 & & & \\
\hline Pseudoanabaena sp. & & 1 & & \\
\hline Spirulina sp. & & & & 1 \\
\hline Synechocystis salina Wislouch & & & 1 & \\
\hline Tetrarcus ilsteri Skuja & & & & 1 \\
\hline Woronichinia sp. & & & & 1 \\
\hline
\end{tabular}

\section{Phyla Heterokontophyta}

Class Bacillariophyceae

Achnanthes exigua Grunow

Amphora ovalis (Kützing) Kützing

Asterionella formosa Hassall

Aulacoseira ambigua (Grunow) Simonsen

Aulacoseira granulata (Ehrenberg) Simonsen

Aulacoseira sp.

Caloneis sp.

Chamaepinnularia obsoleta (Hustedt) Wetzel \& Ector

Cocconeis neodiminuta Krammer

Cocconeis placentula Ehrenberg

Cyclotella glomerata Bachmann

Cyclotella meneghiniana Kützing

Cyclotella ocellata Pantocsek

Cyctotella sp. 1

Cyclotella sp. 2

Cyclotella sp. 3

Cymatopleura solea (Brébisson) Smith

Cymbella affinis Kützing

Cymbella cistula (Ehrenberg) Kirchner

$\begin{array}{lll} & 1 & 1 \\ 2 & & \\ 2 & & \\ 1 & & \\ & & \\ & 1 & \\ 1 & 3 & 1 \\ & & \\ & 4 & \\ & 2 & 2 \\ 3 & 1 \\ & & \\ & & \\ & & \\ & & \end{array}$




\begin{tabular}{|c|c|c|c|c|}
\hline & A & $\mathrm{B}$ & $\mathrm{C}$ & $\mathrm{D}$ \\
\hline Cymbella helvetica Kützing & & 1 & & \\
\hline Cymbella sp. 1 & 1 & & & \\
\hline Cymbella sp. 2 & & 1 & & \\
\hline Cymbella tumida (Brébisson) van Heurck & & & 1 & 1 \\
\hline Denticula $\mathrm{sp}$. & & 1 & & \\
\hline Diatoma anceps (Ehrenberg) Kirchner & 1 & 3 & & \\
\hline Diatoma vulgaris Bory de Saint-Vincent & & & & 2 \\
\hline Encyonema prostratum (Berkeley) Kützing & & 1 & & \\
\hline Epithemia adnata (Kützing) Brébisson & & & 4 & 1 \\
\hline Epithemia sorex Kützing & 1 & 1 & 1 & 1 \\
\hline Epithemia turgida (Ehrenberg) Kützing & & & 1 & 1 \\
\hline Eunotia sp. & & & & 1 \\
\hline Fragilaria capucina Desmazières & & 3 & 1 & 1 \\
\hline Fragilaria construens f. venter (Ehrenberg) Hustedt & & & 1 & \\
\hline Fragilaria crotonensis Kitton & & & 3 & 3 \\
\hline Fragilaria parasitica var. subconstricta Grunow & 1 & & & \\
\hline Fragillaria sp. 1 & & & 2 & \\
\hline Fragillaria sp. 2 & & & & 1 \\
\hline Fragillaria sp. 3 & 2 & & & \\
\hline Fragillaria sp. 4 & & 1 & & \\
\hline Gomphonema acuminatum Ehrenberg & & 2 & 3 & 1 \\
\hline Gomphonema augur Ehrenberg & 1 & 1 & 1 & \\
\hline Gomphonema parvulum var. parvulum (Kützing) Kützing & & & 3 & 3 \\
\hline Gomphonema sp. & & 2 & & \\
\hline Gomphonema truncatum Ehrenberg & 1 & 2 & & 2 \\
\hline Gyrosigma acuminatum (Kützing) Rabenhorst & 2 & 2 & & \\
\hline Gyrosigma sp. & 2 & & & \\
\hline Hippodonta capitata (Ehrenberg) Lange-Bertalot, Metzeltin \& Witkowski & 1 & 1 & & \\
\hline Lemnicola hungarica (Grunow) Round \& Basson & & 3 & & \\
\hline Melosira undulata (Ehrenberg) Kützin & & 2 & & \\
\hline Melosira varians Agardh & 2 & 4 & 1 & 1 \\
\hline Melosira sp. 1 & 2 & & & \\
\hline Melosira sp. 2 & & 3 & & \\
\hline Navicula capitatoradiata Germain & 1 & & & \\
\hline Navicula cincta (Ehrenberg) Ralfs & & & 1 & \\
\hline Navicula radiosa Kützing & & & & 1 \\
\hline Navicula rhynchocephala Kützing & 1 & 2 & 1 & 1 \\
\hline Navicula sp. 1 & & & & 1 \\
\hline Navicula sp. 2 & 1 & & & \\
\hline Navicula sp. 3 & & 3 & & \\
\hline Navicula viridula (Kützing) Ehrenberg & 1 & 1 & & \\
\hline Nitzschia acicularis (Kützing) W. Shmith & & & & 2 \\
\hline Nitzschia amphibia Grunow & 1 & 1 & & \\
\hline Nitzschia cf. nana Grunow & 1 & & & \\
\hline Nitzschia cf. sigmoidea (Nitsch) W. Shmith & 1 & & & \\
\hline Nitzschia cf. supralitorea Lange - Bertalot & & & 1 & \\
\hline Nitzschia draveillensis Coste \& Ricard & 2 & & & \\
\hline Nitzschia amabilis Suzuki & 2 & 1 & & \\
\hline Nitzschia palea (Kutzing) Smith & 1 & & 1 & 1 \\
\hline Nitzschia sp. & 1 & 2 & & \\
\hline Nupela impexiformis (Lange-Bertalot) Lange-Bertalot & 1 & & 1 & \\
\hline Pinnularia cf. maior (Kützing) Cleve & 1 & & & \\
\hline Pinnularia viridis (Nitzsch) Ehrenberg & 1 & 1 & & \\
\hline Pleurosigma salinarum (Grunow) Grunow & 1 & & & \\
\hline Pleurosigma sp. & & & 3 & \\
\hline Pleurosigma sp. & 1 & & & \\
\hline Rhoicosphenia abbreviata (Agardh) Lange-Bertalot & & 2 & & \\
\hline Surirella sp. & & 1 & & \\
\hline Tabellaria sp. & & 1 & & \\
\hline Tabularia fasciculata (Agardh) Williams \& Round & 1 & & & \\
\hline Tryblionella angustata W.Smith & 1 & & 1 & 1 \\
\hline Tryblionella kuetzingii Ãlvarez-Blanco \& Blanco & 1 & 1 & & \\
\hline
\end{tabular}




\begin{tabular}{|c|c|c|c|c|}
\hline & $\mathrm{A}$ & $\mathrm{B}$ & $\mathrm{C}$ & $\mathrm{D}$ \\
\hline Ulnaria ulna (Nitzsch) Compère & 1 & 3 & 3 & 3 \\
\hline \multicolumn{5}{|l|}{ Class Chrysophyceae } \\
\hline cysty Chrysophyceae & 1 & & & \\
\hline Dinobryon divergens Imhof & & 3 & & \\
\hline Epipyxis sp. & 1 & & & \\
\hline
\end{tabular}

\section{Class Xanthophyceae}

Centritractus capillifer Pascher

Characiopsis elegans Ettl

Characiopsis gibba (Braun) Borzi

Characiopsis sp.

Goniochloris smithii (Bourrelly) Fott

Ophiocytium cochleare (Eichwald) Braun

Ophiocytium parvulum (Perty) Braun

Tribonema aequale Pascher

Tribonema pyrenigerum Pascher

Phyla Euglenophyta

\section{Class Euglenophyceae}

Colacium sp. 1

Colacium sp. 2

Colacium sp. 3

Colacium vesiculosum Ehrenberg

Euglena pisciformis Klebs

Euglena ehrenbergii Klebs

Euglena hemichromata Skuja

Euglena sp. 1

Euglena sp. 2

Euglena sp. 3

Euglena sp. 4

Euglenaria anabaena (Mainx) Karnkowska \& Linto

Euglenaria clara Skuja

Euglenaformis proxima (Dangeard) Bennett \& Triemer

Lepocinclis acus (Müller) Marin et Malkonian

Lepocinclis fusiformis (Carter) Lemmermann

Lepocinclis ovum var. alata Swirenko

Lepocinclis oxyuris (Schmarda) Marin \& Melkonian

Lepocinclis texta (Dujardin) Hübner

Lepocinclis tripteris (Dujardin) Marin \& Melkonian

Monomorphina pyrum (Ehrenberg) Mereschkowsky

Peranema sp.

Petalomonas sp.

Phacus acuminatus Stokes

Phacus granum Dreżepolski

Phacus helikoides Pochmann

Phacus limnophilus (Lemmermann) Linton \& Karnkowska-Ishikawa

Phacus longicauda (Ehrenberg) Dujardin

Phacus longicauda var. tortus (Lemmermann) Popova

Phacus orbicularis Hübner

Phacus parvulus Klebs

Phacus pleuronectes (Müller) Nitzsch ex Dujardin

Phacus pusillus Lemmermann

Phacus sp. 1

Phacus sp. 2

Phacus strongylus Pochmann

Strombomonas sp. 1

Strombomonas sp. 2

Trachelomonas hispida (Perty) Stein

Trachelomonas intermedia Dangeard

Trachelomonas lacustris Dreżepolski

Trachelomonas lefevrei Deflandre

Trachelomonas planctonica Swirenko

2

1

1

2

3

1

1

2

1

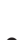

2

1

2

2

2

2

$$
1
$$

1 


\begin{tabular}{|c|c|c|c|c|}
\hline & A & $\mathrm{B}$ & $\mathrm{C}$ & $\mathrm{D}$ \\
\hline Trachelomonas sp. 1 & & & & 2 \\
\hline Trachelomonas sp. 2 & & 2 & & \\
\hline Trachelomonas verrucosa Stokes & & & 1 & \\
\hline Trachelomonas volvocina (Ehrenberg) Ehrenberg & & & & 6 \\
\hline \multicolumn{5}{|l|}{ Phyla Chlorophyta } \\
\hline \multicolumn{5}{|l|}{ Class Chlorophyceae } \\
\hline Acutodesmus acuminatus (Lagerheim) Tsarenko & & & 1 & 2 \\
\hline Ankistrodesmus falcatus var. acicularis (A. Br.) West & & & 1 & \\
\hline Ankistrodesmus fusiformis Corda & 1 & 1 & 1 & \\
\hline Ankistrodesmus gracilis (Reinsch) Korshikov & & & & 2 \\
\hline Aphanochaete repens A. Braun & & & 1 & 1 \\
\hline Chaetophora lobata Schrank & & & 1 & \\
\hline Characium acuminatum A. Braun & & & 1 & 1 \\
\hline Characiopsis subulata var. ensiformis (Hermann) Lemmermann & 1 & & & \\
\hline Chlamydomonas sp. & 1 & & & \\
\hline Chlorella sp. & 1 & & & \\
\hline Chlorobotris sp. & & & 1 & \\
\hline Chloromonas sp. & & 6 & & \\
\hline Coelastrum astroideum De Notaris & & & 2 & \\
\hline Coelastrum microporum Nägeli & & & 1 & 2 \\
\hline Coelastrum pseudomicroporum Korshikov & & & & 2 \\
\hline Coelastrum reticulatum (Dang.) Senn sensu Teil. & & 2 & & \\
\hline Crucigenia tetrapedia (Kirchner) Kuntze & & & & 2 \\
\hline Desmodesmus dispar (Brébisson) Hegewald & 1 & & 1 & \\
\hline Desmodesmus flavescens (Chodat) Hegewald & & & 1 & \\
\hline Desmodesmus magnus (Meyen) Tsarenko & 1 & 2 & 1 & \\
\hline Desmodesmus opoliensis (Richter) Hegewald & 1 & 2 & 1 & 3 \\
\hline Desmodesmus protuberans (Fritsch \& Rich) Hegewald & 3 & 2 & 1 & 3 \\
\hline Desmodesmus spinosus (Chodat) Hegewald & & & 1 & \\
\hline Desmodesmus subspicatus (Chodat) Hegewald \& Schmidt & & 1 & 1 & \\
\hline Golenkinia radiata Chodat & & & & 3 \\
\hline Gonium formosum Pascher & & & & 2 \\
\hline Hydrodictyon reticulatum (Linnaeus) Bory de Saint-Vincent & & & 1 & \\
\hline Kirchneriella dianae (Bohlin) Comas Gonzalez & & & & 2 \\
\hline Lagerheimia marssonii Lemmermann & & & 1 & \\
\hline Lagerheimia wratislaviensis Schröder & 1 & 1 & 1 & 2 \\
\hline Micractinium pusillum Fresenius & & & & 2 \\
\hline Mucidosphaerium pulchellum (Wood) Bock, Proschold \& Krienitz & & 2 & & 2 \\
\hline Oedogonium sp. & & & 1 & 1 \\
\hline Oocystis lacustris Chodat & & & 1 & \\
\hline Oocystis sp. 1 & & & & 1 \\
\hline Oocystis sp. 2 & 1 & & & \\
\hline Pandorina morum (Müller) Bory de Saint-Vincent & 1 & 1 & & \\
\hline Pandorina sp. 1 & & & 1 & \\
\hline Pandorina sp. 2 & 3 & & & \\
\hline Pseudodidymocystis planctonica (Korshikov) Hegewald \& Deason & 1 & 2 & & \\
\hline Pseudopediastrum boryanum (Turpin) Hegewald & & 2 & 1 & 3 \\
\hline Pediastrum duplex Meyen & & & 1 & 2 \\
\hline Scenedesmus aldavei Hegewald & 1 & & & \\
\hline Scenedesmus armatus (Chodat) Chodat & & & 1 & \\
\hline Scenedesmus gutwinskii var. heterospina Bodrogk & 1 & & 1 & \\
\hline Scenedesmus longispina Chodat & 2 & 2 & 1 & 1 \\
\hline Scenedesmus quadricauda (Turpin) Brébisson & 1 & & 1 & 3 \\
\hline Scenedesmus obliquus var. dimorphus (Turpin) Hansgirg & & & & 3 \\
\hline Scenedesmus sp. 1 & & & 1 & \\
\hline Scenedesmus sp. 2 & 1 & & & \\
\hline Scenedesmus sp. 3 & & 3 & & \\
\hline Selenastrum bibraianum Reinsch & & & & 4 \\
\hline Staurastrum sp. & & & & 1 \\
\hline Tetrastrum triacanthum Korshikov & & & 1 & \\
\hline Tetrastrum triangulare (Chodat) Komárek & & & & 1 \\
\hline
\end{tabular}




\begin{tabular}{|c|c|c|c|c|}
\hline & $\mathrm{A}$ & $\mathrm{B}$ & $\mathrm{C}$ & $\mathrm{D}$ \\
\hline Treubaria planctonica (Smith) Korshikov & & & & 1 \\
\hline Ulothrix sp. & & & & 1 \\
\hline \multicolumn{5}{|l|}{ Class Cladophorophyceae } \\
\hline Cladophora glomerata (Linnaeus) Kützing & & 1 & 1 & 3 \\
\hline \multicolumn{5}{|l|}{ Class Zygnematophyceae } \\
\hline Cosmarium sp. & 1 & & & \\
\hline Cosmarium wembaerense Schmidle & 1 & & 1 & 1 \\
\hline Mougeotia sp. 1 & & 1 & 1 & \\
\hline Mougeotia sp. 2 & & & & 2 \\
\hline Spirogyra sp. 1 & 1 & & 1 & 3 \\
\hline Spirogyra sp. 2 & & & 1 & \\
\hline Zygnema sp. & & & 1 & \\
\hline \multicolumn{5}{|l|}{ Phyla Dinophyta } \\
\hline \multicolumn{5}{|l|}{ Class Dinophyceae } \\
\hline Gymnodinium sp. & & 1 & & \\
\hline Katodinium sp. & & & & 1 \\
\hline \multicolumn{5}{|l|}{ PhylaCryptophyta } \\
\hline \multicolumn{5}{|l|}{ Class Cryptophyceae } \\
\hline Cryptomonas sp. & & & & 1 \\
\hline
\end{tabular}

